\title{
Systematic study on protective role of date palm (Phoenix dactylifera L.) on central nervous system disorders
}

\author{
MD Imad Uddin , A. Vandana, G. Kavya and Yousuf Hussain Syed* \\ Department of Pharmacology, Pulla Reddy Institute of Pharmacy, Hyderabad-502313, Telangana State, India \\ *Department of Pharmacognosy, Anwarul Uloom College of Pharmacy, Hyderabad-500001, Telangana State, India
}

\section{Article Info}

Article history

Received 3 April 2020

Revised 19 May 2020

Accepted 21 May 2020

Published online 30 June 2020

Keywords

Date palm

Phoenix dactylifera $\mathrm{L}$.

Central nervous system anti-Alzheimer's activity

Anticonvulsants

\begin{abstract}
Present study was designed to screen the role of Phoenix dactylifera L. (P. dactylifera) in CNS disorders. All the records were summarized according to PRISMA statement of systematic reviews. By applying identification, exclusion, eligibility and inclusion criterias, 17 original research articles were selected. In these studies, P. dactylifera was used as either long term dietary supplementation or aqueous or ethanolic or methanolic extracts. These studies reported different activities such as anti-Alzheimer's, anticonvulsant, cerebral antiischemic, neuroprotective, anxiolytic, nootropic and antipsychotic. Mechanisms underlying anti-Alzheimer's activity of $P$. dactylifera were antioxidant, anxiolytic, cholinomimetic and anti-inflammatory actions. Anticonvulsant activity was due to GABA facilitatory action and blocking of NMDA action. Antioxidant nature of flavonoids, tannins and phenols of $P$. dactylifera showed neuroprotective and cerebral anti-ischemic actions. whereas antipsychotic actions were due to decreased serotonergic and dopaminergic transmissions and increased cholinergic transmission. This systematic study successfully establishes and supports protective role of P. dactylifera in treatment of CNS related disorders and put forth the path to carry out the meta-analyses for increasing the use of safer plant based remedies.
\end{abstract}

\section{Introduction}

Phoenix dactylifera L. belongs to Arecaceae family and commonly called as date palm. It is a foremost cultivated crop since last 5000 years in the Middle East, Arabian and North African countries (Baliga et al., 2011). Chief phytoconstituents found in fruits are anthocyanins such as pelargonin; phenolics such as caffeic acid, chlorogenic acid, cinnamic acid, coumaroylquinic acid, ferulic acid, gallic acid, hydrocaffeic acid o-coumaric acid, p-coumaric acid, p-hydroxybenzoic acid, protocatechuic acid, sinapic acid, syringic acid, vanillic acid, xanthoxylin acid and 5-o-caffeoyl shikimic acid (Karasawa et al., 2011); phytoestrogens such as coumestrol, daidzein, formononetin, genistein, glycitein, lariciresinol, matairesinol, pinoresinol and secoisolariciresinol (Thompson et al., 2006); carotenoids such as $\beta$-carotene, lutein, antheraxanthin, violaxanthin and neoxanthin (Al-Rimawi and Odeh, 2015). Flavonoids include isoquercetrin, rutin (Hamad et al., 2015), diglycosidic apigenin, mono, di and triglycosidic form of both luteolin and Quercetin (Hong et al., 2006), Diosmetin 1 (diosmetin 7-O- $\beta$-Larabinofuranosy (1'!2)- $\beta$-D-apiofuranoside) and Diosmetin 2 (diosmetin 7-Oß-D-apiofuranoside) (Michael et al., 2013).

Traditionally, it was commonly used for varied conditions in different parts of the world. In Morocco, people used it for diabetes and hypertension (Vickers, 2017); pulp boiled in milk as tonic and powdered mixture of almonds, dates, pistachio nuts, spices, quince seeds and sugars as nourishing diet for pregnant and lactating mothers

Corresponding author: Mr. MD Imad Uddin

Associate Professor, Department of Pharmacology, Pulla Reddy Institute of Pharmacy, Hyderabad-502313, Telangana State, India

E-mail: imadpharma111@gmail.com

Tel.: +91-8374175556

Copyright $(\odot 2020$ Ukaaz Publications. All rights reserved.

Email: ukaaz@yahoo.com; Website: www.ukaazpublications.com
(Puri et al., 2000); and also used for anti-aging activity (Meer et al., 2017), bronchitis, burning sensation, cough, gastropathy, nephropathy, rheumatism and sexual debility (El-Hilaly et al., 2018).

Within a short span of last 50 years (1969 to 2019) marvellous beneficial uses of the date fruit have been validated scientifically with in vitro and in vivo studies. Yeh et al. (2009) showed the expression of antioxidant enzyme genes in animals treated with date's p-coumaric acid, Chaira et al. (2009) showed antiradical activity of date flavonoids. Phenolic acids were reported with antimutagenic activity (Birosova $e t$ al., 2005). Abuharfeil et al. (1999) reported antihaemolytic effect of date steroids. Tapas et al. (2008) reported membrane stabilizing effect of date constituents like anthocyanins, carotenoids, flavonoids and procyanidins, Orhan (2010) reported antifungal activity of date ûavonoids, Jassim and Naji (2010) reported antiviral activity of date fruits. Antihyperlipidemic and cardioprotective activity were reported with anthocyanins (Finne Nielsen et al., 2005). Hepatoprotective activity was reported with apigenin (Zheng et al., 2005) caffeic acid and quercetin (Janbaz et al., 2004). Nephroprotective activity was reported with quercetin (Abdel-Raheem et al., 2009). Anticancer activity was reported with $\beta$-glucan (Fullerton et al., 2000). Isorhamnetin, kaempherol and quercetin were reported with immunostimulatory activity (Akbay et al., 2003). Genistein was reported with gonadotropic activity (Eustache et al., 2009). The antidiabetic activity was reported with diosmetin 1 and 2 (Al-Harrasi et al., 2014), genistein and daidzein (Choi et al., 2008). $\beta$-sitosterol (Field et al., 1997) and stigmasterol (Batta et al., 2006) were reported with hypocholesterolemic effect. Antidiarrheal activity was reported with aqueous extract of date fruits (Kumar et al., 2010). By keeping in consideration, the vast clinical applications of $P$. dactylifera, current study was designed to carry out the systematic review of animal research data available in the reported literature. 


\section{Materials and Methods}

\subsection{Study design}

Different databases such as Pubmed, Science Direct, Scopus, Springer and Google Scholar were used to carry out the in-depth search of literature. Mesh terms which were used for carrying out systematic survey are: three plant related terms viz., "Phoenix" OR "Phoenix dactylifera" OR "Date Palm" were used individually in combination with each of the CNS disorder related term viz., "ADHD" OR "Alzheimer's" OR “Anxiety" OR "Anxious" OR "Attention Deficit" OR "Attention Deficit Disorder" OR "Attention Deficit Hyperactivity Disorder" OR “Autistic Spectrum Disorder" OR “Autism” OR “Brain” OR "Central Nervous System" OR “CNS" OR "Cognitive Impairment" OR "Delusion" OR "Dementia" OR "Depression" OR "Depressive Symptoms" OR "Generalized Anxiety Disorder" OR "Hyperactivity Disorder" OR "Major Depression" OR "Neurodegenerative Disease" OR "Neurological Disorders" OR "Neuropsychiatric Disorder" OR "Psychological Disorder" OR "Psychosis" OR "Psychotic Disorder" OR "Schizophrenia" OR "Trauma".

\subsection{Identification, exclusion, eligibility and inclusion basis}

All the published original research studies which used any of the above plant related terms in combination with CNS disorders related terms were identified. Records which have been excluded were duplicate articles and articles which were not relevant to the aim of work. Further screenings of records were conducted to remove items which were not eligible for systematic study. Records which were not eligible were abstracts, commentaries, protocols, book chapters and papers published in conferences, congress, meetings, scientific sessions and symposiums because of inadequate information. Finally, full text articles which were relevant to the aim of work were selected for the study.

\section{Results}

\subsection{Search results}

Intensive screening of all databases identified 4014 records. Extracted data was summarized by using PRISMA guidelines (Figure 1). 1717 duplicate records were excluded; from remaining 2297 records 1754 were excluded as they were not relevant to the aim of the work. 543 records were further screened and 526 records were found not eligible and were removed and finally, 17 full text articles were retained for the systematic study. The summary of these articles is presented in Table 1 . Moreover, the mechanism of $P$. dactylifera was explained in Figure 2.

\subsection{Anti-Alzheimer's activity}

Among the included studies, five were reported with anti-Alzheimer's activity in which three studies used date palm as a part of the diet and among the other two; one used aqueous date fruit extract (ADFE) and another used date seed extract (DSE). Subash et al. (2015) evaluated the effect of date palm fruit in the diet on the transgenic mouse model of Alzheimer's disease (AD) (APPsw/Tg2576). 2\% and 4\% date supplementation for 14 months in APPsw/Tg2576 mice restored locomotor activity, i.e., muscular coordination (rotarod and open field tests), improved escape latency (morris water maze test), reduced anxiety levels (elevated plus maze test), improved position discrimination learning ability (T-maze test). There was also a significant reduction in circulating levels of human amyloid $\beta$ (A $\beta$ ) 1-40 and A $\beta 1-42$ in APPsw/Tg2576 mice received date rich diet. With another group of scientists, Subash et al. (2015) screened the effects of $2 \%$ and $4 \%$ dates supplementation for 15 months on oxidative stress and antioxidant status by using APPsw/ Tg2576 mice. Dietary supplementation considerably reduced the lipid peroxidase (LPO) and protein carbonyl content (PCO) levels, restored normal levels of antioxidant enzymes, alternated the AchE activity and improved $\mathrm{Na}^{+}-\mathrm{K}^{+}$-ATPase activity. Later on, Essa et al. (2015) reported protective effects of only $4 \%$ date palm dietary supplementation against the neuroinflammation in APPsw/Tg2576 mice. The study resulted in recovery of ATP levels (45\%) and significant decrease in plasma cytokines (viz., IL-2, IL-3, IL-4, IL-5, IL-9, IL-10 and Eotaxin), cortex and hippocampus region neuropeptides (viz., A $\beta 1-40$, A $\beta 1-42$, IL-1 $\beta$, TNF$\alpha$, and IL-6) on supplementation with date palm. This study also covered beneficial effects of pomegranates and figs along with date palm.

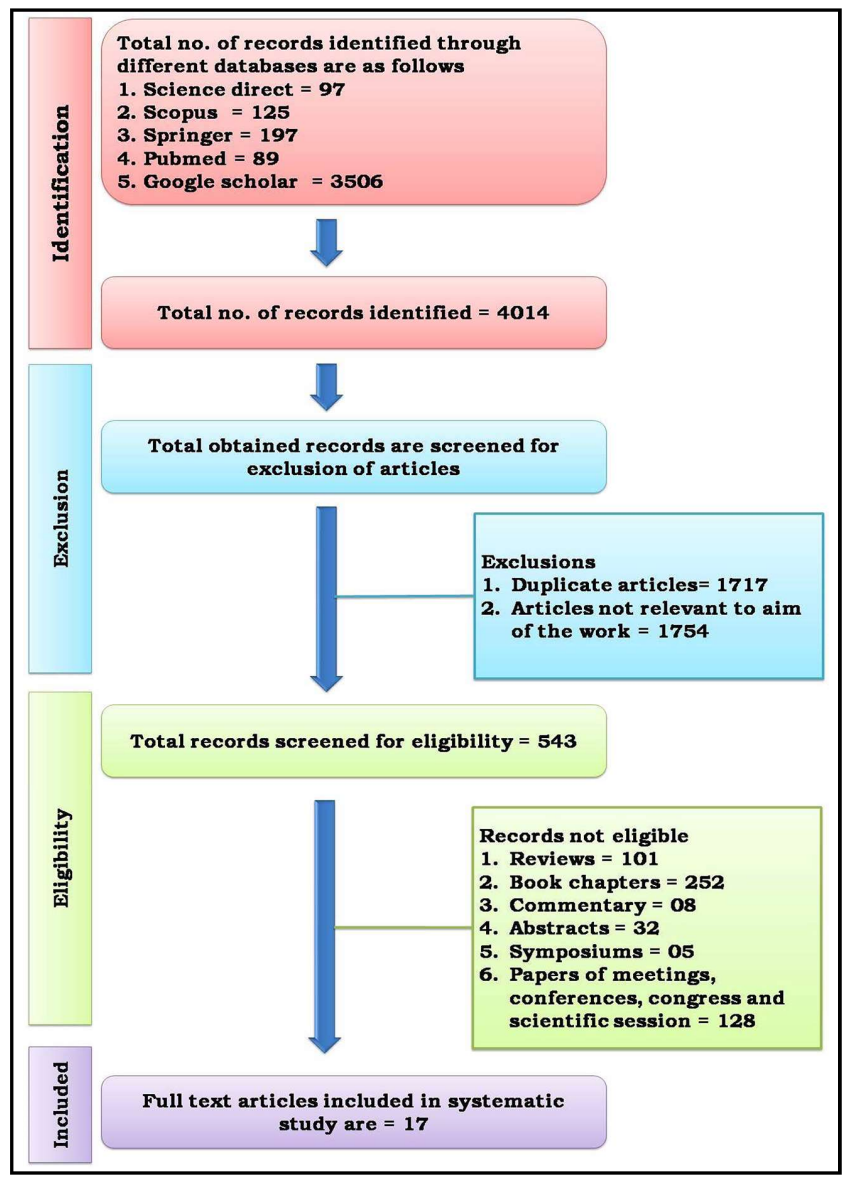

Figure 1: Flow chart explaining identification, exclusion, eligibility and Inclusion process by using PRISMA guidelines.

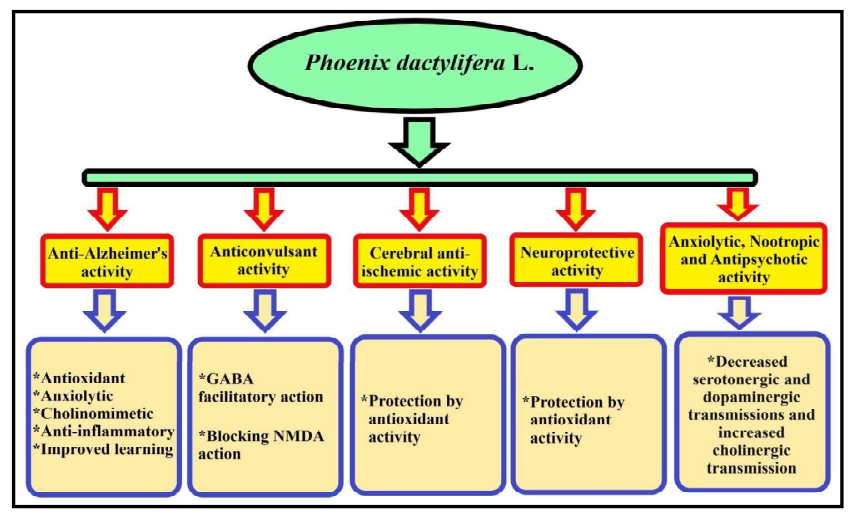

Figure 2: Mechanism of action of $P$. dactylifera in different CNS related disorders. 
Table 1: Brief summary of studies related to $P$. dactylifera and CNS disorders

\begin{tabular}{|c|c|c|c|c|c|c|c|c|}
\hline S.No. & $\begin{array}{l}\text { Diet / Extract / } \\
\text { Constituent } \\
\text { (Dose-mg/kg) }\end{array}$ & $\begin{array}{l}\text { Part } \\
\text { used }\end{array}$ & $\begin{array}{l}\text { CNS related } \\
\text { activity }\end{array}$ & $\begin{array}{l}\text { Method of } \\
\text { induction }\end{array}$ & \begin{tabular}{|c|} 
Study \\
sample
\end{tabular} & $\begin{array}{l}\text { Duration } \\
\text { of study }\end{array}$ & Parameters & Results \\
\hline 1. & $\begin{array}{l}\text { Diet } \\
(2 \% \text { and } 4 \%)\end{array}$ & Fruit & $\begin{array}{l}\text { Anti- } \\
\text { Alzheimer's } \\
\text { activity }\end{array}$ & $\begin{array}{l}\text { APPsw/Tg2576 } \\
\text { Transgenic mice }\end{array}$ & 24 & $\begin{array}{l}14 \\
\text { months }\end{array}$ & $\begin{array}{l}\text { Spatial memory and } \\
\text { learning ability, } \\
\text { psychomotor } \\
\text { coordination, anxiety } \\
\text { and levels of Plasma } \\
\text { amyloid beta } \\
(1-40 \& 1-42)\end{array}$ & $\begin{array}{l}2 \% \text { and } 4 \% \text { date diet supplementation } \\
\text { showed beneficial effects on } \\
\text { cognition, locomotor activity and } \\
\text { significantly lowered both plasma } \\
\text { amyloid beta proteins } \\
\text { (Subash et al., 2015). }\end{array}$ \\
\hline 2. & $\begin{array}{l}\text { Diet } \\
(2 \% \text { and } 4 \%)\end{array}$ & Fruit & $\begin{array}{l}\text { Anti- } \\
\text { Alzheimer's } \\
\text { activity }\end{array}$ & $\begin{array}{l}\text { APPsw/Tg2576 } \\
\text { Transgenic mice }\end{array}$ & 24 & $\begin{array}{l}15 \\
\text { months }\end{array}$ & $\begin{array}{l}\text { Oxidative damage, levels } \\
\text { of antioxidant and } \\
\text { membrane bound } \\
\text { enzymes }\end{array}$ & $\begin{array}{l}2 \% \text { and } 4 \% \text { date diet supplementation } \\
\text { reduced oxidative stress, increased } \\
\text { antioxidant enzyme levels and } \\
\text { restored membrane bound enzyme } \\
\text { activities (Subash et al., 2015). }\end{array}$ \\
\hline 3. & Diet $(4 \%)$ & Fruit & $\begin{array}{l}\text { Anti- } \\
\text { Alzheimer's } \\
\text { activity }\end{array}$ & $\begin{array}{l}\text { APPsw/Tg2576 } \\
\text { Transgenic mice }\end{array}$ & 80 & $\begin{array}{l}15 \\
\text { months }\end{array}$ & $\begin{array}{l}\text { Inflammatory cytokines } \\
\text { estimation, brain content of } \\
\text { Amyloid } \beta \text { (1-40 \& 1-42), } \\
\text { estimation of ATP, assessment } \\
\text { of IL-1 } \beta \text {, TNF- } \alpha \text { and IL-6 }\end{array}$ & $\begin{array}{l}4 \% \text { date diet supplementation } \\
\text { provides protection against the } \\
\text { inflammation in APPsw/Tg } 2576 \\
\text { Transgenic mice brain (Essa et al., 2015). }\end{array}$ \\
\hline 4. & $\begin{array}{l}\text { Aqueous extract } \\
(100,200 \& \\
400)\end{array}$ & Fruit & $\begin{array}{l}\text { Anti- } \\
\text { Alzheimer's } \\
\text { activity }\end{array}$ & \begin{tabular}{|l|} 
Scopolamine \\
$(0.4 \mathrm{mg} / \mathrm{kg}) \& \mathrm{STZ}$ \\
$(0.4 \mathrm{mg} / \mathrm{kg})$ induced \\
memory loss
\end{tabular} & 126 & 30 days & $\begin{array}{l}\text { Antioxidant activity, } \\
\text { Nootropic activity, } \\
\text { AChE activity }\end{array}$ & $\begin{array}{l}\text { ADFE showed antioxidant, nootropic } \\
\text { activity and averted the chemical } \\
\text { induced memory deficiency in mice } \\
\text { (Hussain et al., 2015). }\end{array}$ \\
\hline 5. & $\begin{array}{l}\text { Methanolic } \\
\text { extract }(80)\end{array}$ & Seed & $\begin{array}{l}\text { Anti- } \\
\text { Alzheimer's } \\
\text { activity }\end{array}$ & $\begin{array}{l}\text { Beta-amyloid } \\
\text { induced } \\
\text { hippocampal } \\
\text { damage }\end{array}$ & 24 & 13 days & $\begin{array}{l}\text { Learning and memory } \\
\text { evaluation, Caspase- } 3 \\
\text { expression and neuronal } \\
\text { degeneration. }\end{array}$ & $\begin{array}{l}\text { DSE protected CA1 area of } \\
\text { hippocampus, improved learning and } \\
\text { memory, decreased caspase-3 } \\
\text { expression (Dehghanian et al., 2017). }\end{array}$ \\
\hline 6. & $\begin{array}{l}\text { 3,4-dimethoxy } \\
\text { toluene }(100)\end{array}$ & Spathe & $\begin{array}{l}\text { Anticonvulsant } \\
\text { activity }\end{array}$ & $\begin{array}{l}\text { MES, PTZ, Pic and } \\
\text { Nic induced } \\
\text { convulsions }\end{array}$ & 48 & 1 day & $\begin{array}{l}\text { Convulsions and } \\
\text { mortality }\end{array}$ & $\begin{array}{l}\text { DMT showed anti Convulsant action } \\
\text { and also showed protection against } \\
\text { mortality (Al-Taher, 2008) }\end{array}$ \\
\hline 7. & $\begin{array}{l}\text { Methanol-water } \\
(4: 1 \text { v/v) }(30 \\
100 \& 300)\end{array}$ & Fruit & $\begin{array}{l}\text { Cerebral } \\
\text { anti-ischemic } \\
\text { activity }\end{array}$ & $\begin{array}{l}\text { BCCAO (micro } \\
\text { aneurysmal clips } \\
\text { for } 30 \text { minutes, } \\
\text { followed by } 45 \text { min } \\
\text { reperfusion) }\end{array}$ & 30 & 15 days & $\begin{array}{l}\text { Biochemical Analysis, } \\
\text { Histopathological } \\
\text { examination }\end{array}$ & $\begin{array}{l}\text { MDFE showed significant } \\
\text { neuroprotection by reversing the } \\
\text { changes in biochemical parameters of } \\
\text { brain and also preventing histopathological } \\
\text { alterations (Pujari et al., 2011). }\end{array}$ \\
\hline 8. & $\begin{array}{l}\text { Methanolic } \\
\text { extract }(30, \\
100 \& 300)\end{array}$ & Fruit & $\begin{array}{l}\text { Cerebral anti- } \\
\text { ischemic } \\
\text { activity }\end{array}$ & $\begin{array}{l}\text { BCCAO } \\
\text { (long term hypo } \\
\text { perfusion for } \\
15 \text { days ) }\end{array}$ & 30 & 15 days & $\begin{array}{l}\text { Biochemical analysis- } \\
\text { estimation of TP, SOD, } \\
\text { LPO, CAT, GSH, GPx, GST, } \\
\text { GR. Histopathological } \\
\text { studies }\end{array}$ & $\begin{array}{l}\text { MDFE provided significant } \\
\text { neuroprotection by reversing the } \\
\text { alterations in the biochemical parameters } \\
\text { of the brain produced due to the oxidative } \\
\text { stress induced by BCCAO. Pretreatment } \\
\text { also reserved histoarchitecture of CA1 } \\
\text { Hippocampal region (Pujari et al., 2013). }\end{array}$ \\
\hline 9. & $\begin{array}{l}\text { Methanolic } \\
\text { extract }(30 \\
100 \& 300)\end{array}$ & Fruit & $\begin{array}{l}\text { Cerebral anti- } \\
\text { ischemic } \\
\text { activity }\end{array}$ & $\begin{array}{l}\text { BCCAO (Micro } \\
\text { aneurysmal clips } \\
\text { for } 5 \text { min followed } \\
\text { by reperfusion } \\
\text { for } 4 \text { days.) }\end{array}$ & 30 & 15 days & $\begin{array}{l}\text { Behavioral testing-open } \\
\text { field test, morris water maze; } \\
\text { biochemical analysis- } \\
\text { estimation of TP, SOD, } \\
\text { LPO, CAT, GSH, GPx, GST, } \\
\text { GR; histopathological } \\
\text { examination. }\end{array}$ & $\begin{array}{l}\text { MDFE exhibited significant } \\
\text { neuroprotection against oxidative } \\
\text { stress, neuronal damage and spatial } \\
\text { learning and memory impairment } \\
\text { induced by permanent BCCAO } \\
\text { (Pujari et al., 2014). }\end{array}$ \\
\hline 10. & $\begin{array}{l}\text { Aqueous extract } \\
(80)\end{array}$ & Seed & $\begin{array}{l}\text { Cerebral anti- } \\
\text { ischemic } \\
\text { activity }\end{array}$ & $\begin{array}{l}\text { MCAO (occlusion } \\
\text { for } 30 \text { min, } \\
\text { followed by } \\
\text { reperfusion for } \\
48 \text { hours) }\end{array}$ & 29 & 3 days & $\begin{array}{l}\text { SOD, MDA, TAS measured, } \\
\text { Morphological studies } \\
\text { and behavioral activity }\end{array}$ & $\begin{array}{l}\text { DSE showed decrease in neuronal } \\
\text { damage, improved muscle coordination, } \\
\text { decreased MDA, increased SOD and } \\
\text { TAS as compared to control group } \\
\text { (Kalantaripour et al., 2012). }\end{array}$ \\
\hline 11. & $\begin{array}{l}\text { Aqueous extract } \\
(350)\end{array}$ & Fruit & $\begin{array}{l}\text { Neuroprotective } \\
\text { activity }\end{array}$ & $\begin{array}{l}\text { Lead acetate ( } 800 \\
\mathrm{mg} / \mathrm{kg}) \text { induced } \\
\text { neuronal damage in } \\
\text { the occipital cortex }\end{array}$ & 15 & 8 days & $\begin{array}{l}\text { Histological } \\
\text { examination. }\end{array}$ & $\begin{array}{l}\text { ADFE conferred neuroprotective role } \\
\text { against lead acetate induced } \\
\text { degeneration of neuronal cells } \\
\text { (Joseph et al., 2014). }\end{array}$ \\
\hline 12. & $\begin{array}{l}\text { Aqueous extract } \\
(1000 \& 1500)\end{array}$ & Fruit & $\begin{array}{l}\text { Neuroprotective } \\
\text { activity }\end{array}$ & $\begin{array}{l}\text { Lead acetate } \\
(120 \mathrm{mg} / \mathrm{kg}) \\
\text { induced cerebellar } \\
\text { damage }\end{array}$ & 24 & 28 days & $\begin{array}{l}\text { Histological examination } \\
\text { of the cerebellar cortex } \\
\text { with } \mathrm{H} \text { and } \mathrm{E} \text { stain }\end{array}$ & $\begin{array}{l}\text { ADFE ameliorated lead acetate induced } \\
\text { cerebellar damages such as perineuronal } \\
\text { vacuolations and cytoplasmic } \\
\text { shrinkage in purkinje cells of } \\
\text { cerebellar cortex (Yusuf et al., 2017). }\end{array}$ \\
\hline
\end{tabular}




\begin{tabular}{|c|c|c|c|c|c|c|c|c|}
\hline S.No. & $\begin{array}{l}\text { Diet / Extract / } \\
\text { Constituent } \\
\text { (Dose-mg/kg) }\end{array}$ & $\begin{array}{l}\text { Part } \\
\text { used }\end{array}$ & $\begin{array}{c}\text { CNS related } \\
\text { activity }\end{array}$ & $\begin{array}{l}\text { Method of } \\
\text { induction }\end{array}$ & \begin{tabular}{|c|}
$\begin{array}{c}\text { Study } \\
\text { sample }\end{array}$ \\
\end{tabular} & \begin{tabular}{|l|} 
Duration \\
of study
\end{tabular} & Parameters & Results \\
\hline 13. & $\begin{array}{l}\text { Ethanol extract } \\
(500 \& \text { \& } 1000)\end{array}$ & Fruit & \begin{tabular}{|l|} 
Neuroprotective \\
activity
\end{tabular} & \begin{tabular}{|l|} 
Lead-acetate \\
$(120 \mathrm{mg} / \mathrm{kg})$ \\
induced cortical \\
cerebral alterations
\end{tabular} & 20 & 35 days & $\begin{array}{l}\text { Histological and } \\
\text { histochemical } \\
\text { examination }\end{array}$ & $\begin{array}{l}\text { EDFE ameliorated degenerative } \\
\text { changes in cerebral cortex } \\
\text { (Lazarus } \text { et al., 2018). }\end{array}$ \\
\hline 14. & $\begin{array}{l}\text { Aqueous extract } \\
(500,1000 \& \\
1500)\end{array}$ & Fruit & \begin{tabular}{|l|} 
Neuroprotective \\
activity
\end{tabular} & \begin{tabular}{|l|} 
Artesunate \\
$(300 \mathrm{mg} / \mathrm{kg})$ \\
induced cerebellar \\
damage
\end{tabular} & 20 & 7 days & $\begin{array}{l}\text { Histopathological and } \\
\text { histochemical } \\
\text { examination. }\end{array}$ & $\begin{array}{l}\text { ADFE showed neuroprotective effect } \\
\text { by inhibiting the formation of } \\
\text { vacuoles, degeneration of purkinje } \\
\text { fibers and histoarchitectural change of } \\
\text { cerebellum (Agbon et al., 2014). }\end{array}$ \\
\hline 15. & $\begin{array}{l}\text { Aqueous and } \\
\text { ethanol extract } \\
\text { (Both 500, } \\
1000 \& 1500)\end{array}$ & Fruit & \begin{tabular}{|l|} 
Neuroprotective \\
activity
\end{tabular} & \begin{tabular}{|l|} 
Artesunate- \\
Amodiaquine \\
induced Cerebellar \\
cortex damage
\end{tabular} & 36 & 28 days & $\begin{array}{l}\text { Necrosis, Chromatolysis } \\
\text { and vacuolations of } \\
\text { cerebellar cortex }\end{array}$ & $\begin{array}{l}\text { Both extracts preserved } \\
\text { histoarchitecture in dose dependent } \\
\text { manner (Budaye et al., 2018) }\end{array}$ \\
\hline 16. & $\begin{array}{l}\text { Ethanol extract } \\
(250 \& 500)\end{array}$ & Fruit & $\begin{array}{l}\text { Neuroprotective } \\
\text { activity }\end{array}$ & $\begin{array}{l}\text { Pentobarbitone } \\
\text { induced sleeping } \\
\text { time, open field } \\
\text { test and hole } \\
\text { board test. }\end{array}$ & 24 & 2 days & $\begin{array}{l}\text { Sleeping time, } \\
\text { locomotor activity and } \\
\text { exploratory behavior }\end{array}$ & $\begin{array}{l}\text { Extended sleeping time and reduced } \\
\text { locomotor activity and exploratory } \\
\text { behavior (Sheikh } \text { et al., 2016). }\end{array}$ \\
\hline 17. & $\begin{array}{l}\text { Methanolic } \\
\text { extract }(30,100 \\
\& \text { 300) }\end{array}$ & Fruit & \begin{tabular}{|l|} 
Anxiolytic, \\
Nootropic \\
and \\
Antipsychotic \\
activities
\end{tabular} & \begin{tabular}{|l|} 
Hot-plate test, \\
haloperidol \\
induced catalepsy, \\
sodium nitrate \\
induced \\
respiratory arrest, \\
MES induced \\
convulsions
\end{tabular} & 228 & 7 days & $\begin{array}{l}\text { Motor coordination, } \\
\text { locomotor activity, } \\
\text { analgesic, anxiolytic } \\
\text { and anticonvulsant } \\
\text { effects, cognition and } \\
\text { hypoxic effects. }\end{array}$ & $\begin{array}{l}\text { MDFE possesses significant anxiolytic, } \\
\text { analgesic, nootropic and antipsychotic } \\
\text { activities (Vyawahare et al., 2009). }\end{array}$ \\
\hline
\end{tabular}

Instead of using long term date dietary supplementation, Hussain et al. (2015) used ADFE for screening anti-Alzheimer's activity. ADFE showed no AChE activity, a dose-dependent DPPH free radical scavenging activity $(\mathrm{IC} 50=3.5 \mathrm{mg} / \mathrm{ml})$ and significant increase $(p<0.05)$ in Inflexion ratio in elevated plus maze test. Further, ADFE also showed statistically significant $p<0.001$ and $p<0.01$ increase in Inflexion ratio in scopolamine and Streptozotocin (STZ) induced amnesia respectively on elevated plus maze apparatus. Later on Dehghanian et al. (2017) evaluated the neuroprotective effect of DSE in the treatment of AD in the rat model. DSE showed free radical scavenging activity against DPPH radicals, significant decrease in path length and escape latency in Morris water maze test, decrease in expression of caspase-3 and detrimental effects of $\beta$-amyloid induced insults.

\subsection{Anticonvulsant activity}

Only one study was reported with anticonvulsant efficacy of date palm. 3, 4-dimethoxy toluene (DMT), the major constituent of date palm spathe was reported to delay both the onset of convulsions and onset of death and produced $50-100 \%$ protection against mortality in pentylenetetrazole (PTZ), picrotoxin (Pic), nicotine (Nic) and maximal electroshock (MES) epileptic models (Al-Taher, 2008). Moreover Vyawahare et al. (2009) reported no significant action of methanolic date fruit extract (MDFE) in MES induced convulsions.

\subsection{Cerebral anti-ischemic activity}

Cerebral ischemia is also a major cause of neuro degeneration. A total of four studies were identified in which date palm showed protective role in cerebral ischemic conditions. Among them three were conducted on rats challenged with global cerebral ischemia and one on rats challenged with focal cerebral ischemia. Pujari et al. (2011) conducted a study to evaluate the antioxidant and neuroprotective effects of MDFE against global cerebral ischemia induced by bilateral common carotid artery occlusion (BCCAO) in rats. The 15 days pre-treatment with MDFE significantly attenuated neuronal loss and also attenuated all biochemical parameters except depletion of glutathione peroxidase (GPx) and glutathione Stransferase (GST) levels. Later on Pujari et al. (2013) reported neuroprotective effect of MDFE against BCCAO challenged rats. MDFE decreased neurological scores (MCgraw, 1997), attenuated the change of all biochemical enzymes like catalase (CAT), superoxide dismutase (SOD), glutathione (GSH), GST, GPx, glutathione reductase (GR), malondialdehyde (MDA) and also blocked necrotic changes of Cornu Ammonis (CA) as compared to BCCAO control rats. Similarly Pujari et al. (2014) reconfirmed the neuroprotective role of MDFE against BCCAO challenged rats. Post treatment for 15 days with MDFE showed a significant decrease in MDA, significant increase in GSH, GPx, GST, CAT, SOD, improved memory and spatial learning (Morris water maze test), decreased anxiety and restlessness (open field test); and attenuated shrinkage and necrosis of neurons (histopathological examinations).

Kalantaripour et al. (2012) showed a protective role of DSE against focal cerebral ischemia induced by Middle Cerebral Artery Occlusion (MCAO). In the experimental group after reperfusion $80 \mathrm{mg} / \mathrm{kg}$ of DSE was administered by the intraperitoneal route. These animals showed $30.33 \%$ of neuronal damage, attenuation of neural degenerative changes, improved motor coordination, a significant decrease in MDA and increase in SOD, total antioxidant levels (TAS) as compared to the ischemic group. 


\subsection{Neuroprotective activity}

A total of six studies were reported with neuroprotective activity of date fruit extract. In first three studies lead acetate was used, in fourth study alone artesunate was used and in fifth study artesunate and amodiaquine was used in combination to induce cerebellar damages. Joseph et al. (2014) and Yusuf et al. (2017) reported normal cytoarchitecture in cortical regions of lead acetate challenged animals after treatment with ADFE. These two studies also reported the normal histological cerebral cortex appearance in animals receiving only ADFE without lead acetate challenge. Later on Lazarus et al. (2018) reported mild histo-architectural distortions such as pyknosis and cytoplasmic vacuolation in lead acetate challenges animals treated with ethanol date fruit extract (EDFE).

Agbon et al. (2014) reported the animal groups treated with ADFE challenged with artesunate showed mild distortion of histoarchitecture of the cerebellar cortex. Later on Budaye et al. (2018) reported more improved effects of ADFE than EDFE in cytoarchitecture of cerebellar cortex of Artesunate and Amodiaquine challenged rats.

Animals treated with EDFE of all three varieties, viz., Ajwah, Safawy and Sukkari showed increased duration of sleep and reduced time for the onset of sleep (Pentobarbitone induced sleeping time test), decreased locomotor activity (Open field test), decreased number of head dippings (Hole board test), decreased writhing (Acetic acid test), increased response time (Hot plate test) as compared to control mice. HPLC analysis showed the presence of transferulic acid in all the 3 varieties; (+) catechin and (-) epicatechin in Ajwah and Safaway; caffeic acid and P-coumaric acid in Sukkari only and Rosmarinic acid in Ajwah only (Sheikh et al., 2016).

3.6 Anxiolytic, nootropic and antipsychotic activities

Animals treated with MDFE showed proper muscular coordination, optimum locomotor activity (Actophotometer test), significant increase in reaction time (Hot plate test), anxiolytic activity (Elevated plus maze test and double unit mirrored chamber test), intensified catalepsy (Haloperidol test), significant delayed in the onset of death (Sodium nitrite test) and significant increase in discrimination index (Object recognition test) as compared to control animals (Vyawahare et al., 2009).

\section{Discussion}

Anti-Alzheimer's activity of date palm was screened by using APPsw/Tg2576 mice. Abnormal behavior of this mouse was due to the anxiogenic effect caused by the deposition of $\beta$-amyloid peptides. Formation of $\beta$-amyloid plaques was also accelerated by IL-1 $\beta$, IL-6 and tumor necrosis factor- $\alpha$ (TNF- $\alpha$ ) (Patterson, 1995). $\beta$-amyloid plaques and neurofibrillary tangles activate astrocytes and microglia (Engelhart et al., 2004). These animals showed increased levels of different inflammatory cytokines, LPO, PCO levels and AChE activity and inhibition in $\mathrm{Na}^{+}-\mathrm{K}^{+}$-ATPase activity, decreased circulating levels of $A \beta 1-40$ and $A \beta 1-42$, significant decreased levels of ATP (a requisite for neuronal survival) and oxidative parameters in cerebral cortex and hippocampus regions. Since, drug treatment is not curative but it is supportive and will not alleviate the exact root cause of the disease (Kuo and Rajesh, 2017). Many studies have reported the use of fruits and vegetables in the diet as a treatment option for AD. Subash et al. (2015) and
Essa et al. (2015) reported that date palm dietary supplementation for 14 to 15 months restored all these abnormalities of APPsw/ $\operatorname{Tg} 2576$ mice. These beneficial effects of date fruits were due to anxiolytic activity. The reduction of inflammatory cytokines in both plasma and brain were due to the antioxidant action of phytoconstituents like ferulic acid (Kim et al., 2004), protocatechuic acid (Matsumoto et al., 2004) and caffeic acid (Huang et al., 2013) against A $\beta$ induced toxicities. Al-Shahib and Marshall, (2003) also reported the existence of polyphenols in date palm fruits thus proving their role to neutralize the toxicity of oxygen free radicals

In some studies, instead of using APPsw/Tg2576 mice, normal mouse was used to develop AD. Scopolamine and STZ was used to induce amnesia which was due to oxidative stress. This was relieved by ADFE indicating its cholinomimetic potential. Further, the role of AChE was screened and no ADFE dose produced a significant decrease in AChE activity revealing more support towards cholinomimetic activity. Different phytoconstituents of ADFE like phenols and flavonoids plays a major role in relieving oxidative stress (Hussain et al., 2015). In another study $\beta$-amyloid was injected to develop $\mathrm{AD}$. $\beta$-amyloid plaques causes damage to the cell membrane and severe degenerative changes in cortical neurons. These detrimental effects were due to increased expression of caspase-3 and generation of reactive oxygen species. All these $\beta$-amyloid induced insults are prevented by antioxidant property of DSE (Dehghanian et al., 2017). Vayalil, (2012) also reported the antioxidant, neuroprotective potential of DSE. Thus usage of fruits is beneficial in controlling AD. Many other fruit extracts were also reported with anti-Alzheimer's activity viz., $\beta$-amyloid toxicity was controlled by walnut extract (Muthaiyah et al., 2011), memory improvement by pomegranate (Hartman, 2006), cognitive improvement by Ginkgo biloba (Oken et al., 1998).

After AD another challenging CNS related disorder is epilepsy. According to the $20^{\text {th }}$ June 2019 report of WHO, 50 million people globally, are suffering from epilepsy- a chronic brain disorder. Globally, research was focused on discovering new potent synthetic molecules like coumarin derivatives (Tippu et al., 2018) and plant phytoconstituents (Imad Uddin et al., 2017) for the treatment of epilepsy. Efficacy of DMT against PTZ and Pic induced seizures was found to be due to stimulation of GABA pathway and an increase in GABA levels respectively. Moreover, protection against Nic-induced seizures was due to blocking of NMDA receptor or by decreasing NO formation.

Cerebral ischemia is also a major cause of neuro degeneration. BCCAO caused decrease in levels of CAT, GSH, GST, SOD, GR, GPx, and significant increase in the levels of LPO, neurological score, infiltration of inflammatory mediators, vacuolization and death of neurons in the CA, shrinkage and atrophy of neurons in other brain areas of the ischemic rats as compared to the sham group rats. These animals also showed anxiety and restlessness, decrease in memory and spatial learning. Whereas animals with focal ischemia showed death of cortical neurons (indicated by swelling of neuronal organelles, aggregation of chromatin and dark nucleus), motor incoordination, weak muscles, a significant increase in MDA and decrease in SOD and total antioxidant levels. These damaging effects of BCCAO and MCAO were relieved with polyphenolic compounds (flavonoids) of MDFE and DSE. Hence these findings provide a promising use of $P$. dactylifera in stroke and vascular dementia in $\mathrm{AD}$ and age-related memory disturbances. (Pujari et al., 2014; Kalantaripour et al., 2012). 
Lead acetate is toxic to both humans and animals (Wade et al., 2002). Animals challenged with lead acetate showed neurodegenerative effects like shrinkage of cytoplasm, satellitosis, perineuronal vacuolation in molecular layer cells and Purkinje cells of the cerebellar cortex. All these lead acetate insults are controlled in animals treated with ADFE and EDFE. The protective role of $P$. dactylifera was due to antioxidant, chelating and scavenging activity of flavonoids (Lazarus et al., 2018). Widely used antimalarial drug artesunate either alone or in combination with Amodiaquine was also reported to cause distortion in the histoarchitecture of the cerebellar cortex such as neuronal cell loss, neuronal vacuolation, complete loss of Purkinje cell dendrites, and nuclear pyknosis. Neuroprotective role of ADFE against these insults was may be due to the presence of antioxidant compounds like flavonoids, saponins, and tannins (Agbon et al., 2014; Budaye et al., 2018). These studies are in accordance with Pasha et al. (2015) where these constituents were reported to possess potent antioxidant activity.

Moreover, $P$. dactylifera was also reported to possess analgesic, anxiolytic, nootropic and antipsychotic activities. These may be due to decreased serotonergic and dopaminergic transmissions and increased cholinergic transmission (Vyawahare et al., 2009). Later on Sheikh et al. (2016) reported analgesic and neuropharmacological activity of three varieties of dates, viz., ajwa, safawy and sukkari. The effect of ajwa extract was stronger than the safawy and sukkari extracts due to the highest concentration of transferulic acid.

\section{Conclusion}

This study summarizes many beneficial aspects of the miracle plant date palm. Authors can put forth the vast usage of this plant all over the world for long times not only as a medicine but also as a part of the diet. This review covered three studies showing the Neuro-beneficial effects of diet supplementation of date fruits. The study also recapitulates various underlying mechanisms of P. dactylifera, viz., antioxidant, anxiolytic, cholinomimetic, antiinflammatory, GABA facilitator and blocking NMDA action. All these mechanisms may be due to the vast variety of phytoconstituents present in seeds and fruits of this plant. P. dactylifera possesses neurobehavioral and neuroprotective properties because of these essential mechanisms and possesses treatment efficacy in many CNS related disorders like epilepsy, Alzheimer's disease, cerebral ischemic conditions, anxiety and psychosis. P. dactylifera due to its antioxidant action also provided protection against amodiaquine, artesunate and lead acetate induced cerebellar damages. By taking into consideration of all the above-discussed postulates, this study promotes to carry out a meta-analysis along with its wider and safer usage. Leading molecules should be isolated and developed from $P$. dactylifera which may serve as a recognizable treatment option for these globally challenging diseases.

\section{Conflict of interest}

The authors declare that there are no conflicts of interest in the course of conducting the research. All the authors had final decision regarding the manuscript and decision to submit the findings for publication.

\section{References}

Abdel-Raheem, I.T.; Abdel-Ghany, A.A. and Mohamed, G.A. (2009). Protective effect of quercetin against gentamicin-induced nephrotoxicity in rats. Biological and Pharmaceutical Bulletin, 32(1):61-67.

Abuharfeil, N.M.; Sukhon, S.E.; Msameh, Y. and Sallal, A.K.J. (1999). Effect of date fruits, Phoenix dactyliferia L., on the hemolytic activity of streptolysin O. Pharm Biol., 37(5):335-339.

Agbon, A.N.; Ingbian, S.D. and Dahiru, A.U. (2014). Preliminary histological and histochemical studies on the neuroprotective effect of aqueous fruit extract of Phoenix dactylifera L.(Date Palm) on atesunateinduced cerebellar damage in wistar rats. Sub-Saharan African Journal of Medicine, 1(4):204-209.

Akbay, P.; Basaran, A.A.; Undeger, U. and Basaran, N. (2003). In vitro immunomodulatory activity of flavonoid glycosides from Urtica dioica L. Phytother Res., 17(1):34-37.

Al-Harrasi, A.; Rehman, N.U.; Hussain, J.; Khan, A.L.; Al-Rawahi, A.; Gilani, S.A.; Al-Broumi, M. and Ali, L. (2014). Nutritional assessment and antioxidant analysis of 22 date palm (Phoenix dactylifera) varieties growing in Sultanate of Oman. Asian Pac. J. Trop. Med., 7:S591-S598.

Al-Rimawi, F. and Odeh, I. (2015). Development and Validation of an HPLCUV Method for Determination of Eight Phenolic Compounds in Date Palms. J. AOAC Int., 98(5):1335-1339.

Al-Shahib, W. and Marshall, R.J. (2003). The fruit of the date palm: Its possible use as the best food for the future?. Int. J. Food Sci. Nutr., 54(4):247-259.

Al-Taher, A.Y. (2008). Anticonvulsant effects of 3, 4-Dimethoxy toluene, the major constituent of Phoenix dactylifera L. Spathe in mice. Scientific Journal of King Faisal University (Basic and Applied Sciences), 9(2):115-123.

Baliga, M.S.; Baliga, B.R.V.; Kandathil, S.M.; Bhat, H.P. and Vayalil, P.K. (2011). A review of the chemistry and pharmacology of the date fruits (Phoenix dactylifera L.). Food Res. Int., 44(7):1812-1822.

Batta, A.K.; Xu, G.; Honda, A.; Miyazaki, T. and Salen, G. (2006). Stigmasterol reduces plasma cholesterol levels and inhibits hepatic synthesis and intestinal absorption in the rat. Metabolis., 55(3):292-299.

Birosova, L.; Mikulasova, M. and Vaverkova, S. (2005). Antimutagenic effect of phenolic acids. Biomed. Pap., 149(2):489-491.

Budaye, M.N.; Adebisi, S.S.; Buraimoh, A.A.; Lazarus, S.S. and Agbon, A.N. (2018). Comparative study of the effects of aqueous and ethanol fruit extracts of Phoenix dactylifera L. on the cerebellar cortex of Artesunate-Amodiaquine treated adult Wistar rats. Afr. J. Cell. Path., 9(2):16-24.

Chaira, N.; Smaali, M.I.; Martinez-Tome, M.; Mrabet, A.; Murcia, M.A. and Ferchichi, A. (2009). Simple phenolic composition, flavonoid contents and antioxidant capacities in water-methanol extracts of Tunisian common date cultivars (Phoenix dactylifera L.). Int. J. Food Sci. Nutr., 60(7):316-329.

Choi, M.S.; Jung, U.J.; Yeo, J.K.M.J.; Kim, M.J. and Lee, M.K. (2008). Genistein and daidzein prevent diabetes onset by elevating insulin level and altering hepatic gluconeogenic and lipogenic enzyme activities in non obese diabetic (NOD) mice. Diabetes Metab. Res., 24(1):74-81.

Dehghanian, F.; Kalantaripour, T.P.; Esmaeilpour, K.; Elyasi, L.; Oloumi, H.; Pour, F.M. and Asadi-Shekaari, M. (2017). Date seed extract ameliorates $\beta$-amyloid-induced impairments in hippocampus of male rats. Biomed. Pharmacother., 89:221-226. 
El-Hilaly, J.; Ennassir, J.; Benlyas, M.; Alem, C.; Amarouch, M.Y. and FilaliZegzouti, Y. (2018). Anti-inflammatory properties and phenolic profile of six Moroccan date fruit (Phoenix dactylifera $\mathrm{L}$.) varieties. Journal of King Saud University-Science, 30(4):519-526.

Engelhart, M.J.; Geerlings, M.I.; Meijer, J.; Kiliaan, A.; Ruitenberg, A.; van Swieten, J.C.; Stijnen, T.; Hofman, A.; Witteman, J.C. and Breteler, M.M. (2004). Inflammatory proteins in plasma and the risk of dementia: the rotterdam study. Arch. Neurol., 61(5):668-672.

Essa, M.M.; Subash, S.; Akbar, M.; Al-Adawi, S. and Guillemin, G.J. (2015). Longterm dietary supplementation of pomegranates, figs and dates alleviate neuroinflammation in a transgenic mouse model of Alzheimer's disease. PLoS One, 10(3):e0120964.

Eustache, F.; Mondon, F.; Canivenc-Lavier, M.C.; Lesaffre, C.; Fulla, Y.; Berges, R.; Cravedi, J.P.; Vaiman, D. and Auger, J. (2009). Chronic dietary exposure to a low-dose mixture of genistein and vinclozolin modifies the reproductive axis, testis transcriptome, and fertility. Environ. Health Persp., 117(8):1272-1279.

Field, F.J.; Born, E. and Mathur, S.N. (1997). Effect of micellar beta-sitosterol on cholesterol metabolism in $\mathrm{CaCo}-2$ cells. J. Lipid. Res., 38(2):348-360.

Finne Nielsen, I.L.; Elbol Rasmussen, S.; Mortensen, A.; Ravn Haren, G.; Ping Ma, H.; Knuthsen, P.; Fischer Hansen, B.; McPhail, D.; Freese, R.; Breinholt, V. and Frandsen, H. (2005). Anthocyanins increase low density lipoprotein and plasma cholesterol and do not reduce atherosclerosis in Watanabe Heritable Hyperlipidemic rabbits. Mol. Nutr. Food Res., 49(4):301-308.

Fullerton, S.A.; Samadi, A.A.; Tortorelis, D.G.; Choudhury, M.S.; Mallouh, C.; Tazaki, H. and Konno, S. (2000). Induction of apoptosis in human prostatic cancer cells with beta-glucan (Maitake mushroom polysaccharide). Mol. Urol., 4(1):7-13.

Hamad, I.; AbdElgawad, H.; Al Jaouni, S.; Zinta, G.; Asard, H.; Hassan, S.; Hegab, M.; Hagagy, N. and Selim, S. (2015). Metabolic analysis of various date palm fruit (Phoenix dactylifera L.) cultivars from Saudi Arabia to assess their nutritional quality. Molecules, 20(8):13620-13641.

Hartman, R.E.; Shah, A.; Fagan, A.M.; Schwetye, K.E.; Parsadanian, M.; Schulman, R.N.; Finn, M.B. and Holtzman, D.M. (2006). Pomegranate juice decreases amyloid load and improves behavior in a mouse model of Alzheimer's disease. Neurobiol. Dis., 24(3):506-515.

Hong, Y.J.; Tomas-Barberan, F.A.; Kader, A.A. and Mitchell, A.E. (2006). The flavonoid glycosides and procyanidin composition of Deglet Noor dates (Phoenix dactylifera). J. Agr. Food Chem., 54(6):2405-2411.

Huang, Y.; Jin, M.; Pi, R.; Zhang, J.; Chen, M.; Ouyang, Y.; , Liu, A.; Chao, X.; Liu, P.; Liu, J. and Ramassamy, C. (2013). Protective effects of caffeic acid and caffeic acid phenethyl ester against acrolein-induced neurotoxicity in HT22 mouse hippocampal cells. Neurosci. Lett., 535:146-151.

Hussain, S.M.; Awwad, I.A.; Taha, M. and Khan, O. (2015). A laboratory quest on use of date fruit (Phoenix Dactylifera, L) extract in prevention of chemically induced memory deficit models in mice. Asian Journal of Biomedical and Pharmaceutical Sciences, 5(49):5-11.

Imad Uddin, M.D.; Kalyani, D.; Tejasri, N.; Mounika, A.; Sowndarya, A.; Anitha, J. and Ashwaq Hussain, M.D. (2017). Green synthesis and characterization of silver nanoparticles using Glycine max L. seed extract and their antiepileptic activity in rats. Int. J. Pharm. Sci. Nanotech., 10(6):3909-3914.

Janbaz, K.H.; Saeed, S.A. and Gilani, A.H. (2004). Studies on the protective effects of caffeic acid and quercetin on chemical-induced hepatotoxicity in rodents. Phytomedicine, 11(5):424-430.
Jassim, S.A. and Naji, M.A. (2010). In vitro evaluation of the antiviral activity of an extract of date palm (Phoenix dactylifera L.) pits on a Pseudomonas phage. Evid-Based Compl. Alt., 7(1):57-62.

Joseph, O.O.; Babatunde, O.A. and Ayokunle, O. (2014). Phoenix dactylifera conferred neuroprotection against lead acetate induced neuronal damage on the occipital cortex of Wistar rats. Rawal Medical Journal, 39(1):78-80.

Kalantaripour, T.P.; Asadi-Shekaari, M.; Basiri, M. and Najar, A.G. (2012). Cerebroprotective effect of date seed extract (Phoenix dactylifera) on focal cerebral ischemia in male rats. J. Biol. Sci., 12(3):180-185.

Karasawa, K.; Uzuhashi, Y.; Hirota, M. and Otani, H. (2011). A matured fruit extract of date palm tree (Phoenix dactylifera L.) stimulates the cellular immune system in mice. J. Agr. Food Chem., 59(20):11287-11293.

Kim, H.S.; Cho, J.Y.; Kim, D.H.; Yan, J.J.; Lee, H.K.; Suh, H.W. and Song, D.K. (2004). Inhibitory effects of long-term administration of ferulic acid on microglial activation induced by intracerebroventricular injection of $\beta$-amyloid peptide (1-42) in mice. Biol. Pharm. Bull., 27(1):120-121.

Kumar, R.; Sharma, R.J.; Bairwa, K.; Roy, R.K. and Kumar, A. (2010). Pharmacological review on natural antidiarrhoel agents. Der. Pharma Chemica., 2(2):66-93.

Kuo, Y.C. and Rajesh, R. (2017). A critical overview of therapeutic strategy and advancement for Alzheimer's disease treatment. J. Taiwan Inst. Chem. E., 77:92-105.

Lazarus, S.S.; Adebisi, S.S.; Tanko, Y.; Agbon, A.N. and Budaye, M.N. (2018). Histological and histochemical assessements on the effect of ethanol fruit extract of Phoenix dactylifera L.(Date Palm) on cerebral cortex of lead acetate treated wistar rats. Afr. J. Cell. Path., 10(1):1-9.

Matsumoto, K.; Horie, S.; Ishikawa, H.; Takayama, H.; Aimi, N.; Ponglux, D. and Watanabe, K. (2004). Antinociceptive effect of 7-hydroxymitragynine in mice: Discovery of an orally active opioid analgesic from the Thai medicinal herb Mitragyna speciosa. Life Sci., 74(17):2143-2155.

McGraw, C.P. (1977). Experimental cerebral infarction effects of pentobarbital in Mongolian gerbils. Arch. Neurol., 34:334-336.

Meer, S.; Akhtar, N.; Mahmood, T. and Igielska-Kalwat, J. (2017). Efficacy of Phoenix dactylifera L.(Date Palm) creams on healthy skin. Cosmetics, 4(2):13:1-8.

Michael, H.N.; Salib, J.Y. and Eskander, E.F. (2013). Bioactivity of diosmetin glycosides isolated from the epicarp of date fruits, Phoenix dactylifera, on the biochemical profile of alloxan diabetic male rats. Phytother. Res., 27(5):699-704.

Muthaiyah, B.; Essa, M.M.; Chauhan, V. and Chauhan, A. (2011). Protective effects of walnut extract against amyloid beta peptide-induced cell death and oxidative stress in PC12 cells. Neurochem. Res., 36(11):2096-2103.

Oken, B.S.; Storzbach, D.M. and Kaye, J.A. (1998). The efficacy of Ginkgo biloba on cognitive function in Alzheimer disease. Arch. Neurol., 55(11):1409-1415.

Orhan, D.D.; Ozcelik, B.; Ozgen, S. and Ergun, F. (2010). Antibacterial, antifungal, and antiviral activities of some flavonoids. Microbiol. Res., 165(6):496-504.

Pasha, S.G.; Shamshudin, S.K.; Ahamed, S.Y.; Imad Uddin, M.D.; Roshan, S. and Saffon Ali Khan, M.D. (2015). Evaluation of antiepileptic and antioxidant activity of methanolic extract of Terminalia tomentosa \{roxb.\} wight and arn in rats. World Journal of Pharmaceutical Research, 4(2):766-776. 
Patterson, P.H. (1995). Cytokines in Alzheimer's disease and multiple sclerosis. Curr. Opin. Neurobiol., 5(5):642-646.

Pujari, R.R.; Vyawahare, N.S. and Kagathara, V.G. (2011). Evaluation of antioxidant and neuroprotective effect of date palm (Phoenix dactylifera L.) against bilateral common carotid artery occlusion in rats. Indian J. Exp. Biol., 49:627-633.

Pujari, R.R.; Vyawahare, N.S. and Thakurdesai, P.A. (2013). Protective effects of Phoenix dactylifera against oxidative stress and neuronal damage induced by global cerebral ischemia in rats. Biomedicine and Ageing Pathology, 3(2):75-81.

Pujari, R.R.; Vyawahare, N.S. and Thakurdesai, P.A. (2014). Neuroprotective and antioxidant role of Phoenix dactylifera in permanent bilateral common carotid occlusion in rats. Journal of Acute Disease, 3(2):104-114.

Puri, A.; Sahai, R.; Singh, K.L.; Saxena, R.P.; Tandon, J.S. and Saxena, K.C. (2000). Immunostimulant activity of dry fruits and plant materials used in Indian traditional medical system for mothers after child birth and invalids. J. Ethnopharmacol., 71(1-2):89-92.

Sheikh, B.Y.; Zihad, S.N.K.; Sifat, N.; Uddin, S.J.; Shilpi, J.A.; Hamdi, O.A.; Hossain, H.; Rouf, R. and Jahan, I.A. (2016). Comparative study of neuropharmacological, analgesic properties and phenolic profile of Ajwah, Safawy and Sukkari cultivars of date palm (Phoenix dactylifera). Oriental Pharmacy and Experimental Medicine, 16(3): 175-183.

Subash, S.; Essa, M.M.; Al-Asmi, A.; Al-Adawi, S.; Vaishnav, R. and Guillemin, G.J. (2015). Effect of dietary supplementation of dates in Alzheimer's disease APPsw/2576 transgenic mice on oxidative stress and antioxidant status. Nutr. Neurosci., 18(6):281-288.

Subash, S.; Essa, M.M.; Braidy, N.; Awlad-Thani, K.; Vaishnav, R.; Al-Adawi, S.; Al-Asmi, A. and Guillemin, G.J. (2015). Diet rich in date palm fruits improves memory, learning and reduces beta amyloid in transgenic mouse model of Alzheimer's disease. Journal of Ayurveda and Integrative Medicine, 6(2):111-120.

Tapas, A.R.; Sakarkar, D.M. and Kakde, R.B. (2008). Flavonoids as nutraceuticals: A review. Trop. J. Pharm. Res., 7(3):1089-1099.
Thompson, L.U.; Boucher, B.A.; Liu, Z.; Cotterchio, M. and Kreiger, N. (2006). Phytoestrogen content of foods consumed in Canada, including isoflavones, lignans, and coumestan. Nutr. cancer., 54(2):184-201.

Tippu, A.H.; Imad Uddin, M.D.; Chanabasappa, K.B. and Pradeep, R. (2018). Evaluation of neuroprotective potential of some newly synthesized benzopyran-2-one derivatives in swiss albino mice. Indian J. Pharm. Educ., 52(4):S326-S332.

Vayalil, P.K. (2012). Date fruits (Phoenix dactylifera Linn): An emerging medicinal food. Crit. Rev. Food Sci., 52(3):249-271.

Vickers, N.J. (2017). Animal communication: When I'm calling you, will you answer too? Curr. Biol., 27(14):R713-R715.

Vyawahare, N.S.; Pujari, R.R.; Rajendran, R.; Khsirsagar, A.D.; Ingawale, D.K. and Patil, M.N. (2009). Neurobehavioral effects of Phoenix dactylifera in mice. J. Young Pharmacists., 1(3):225-232.

Wade, M.G.; Foster, W.G.; Younglai, E.V.; McMahon, A.; Leingartner, K.; Yagminas, A.L.; Blakey, D.; Fournier, M.; Desaulniers, D. and Hughes, C.L. (2002). Effects of subchronic exposure to a complex mixture of persistent contaminants in male rats: Systemic, immune, and reproductive effects. Toxicol. Sci., 67(1):131-143.

World Health Organisation (WHO) global report on Epilepsy (2019). Geneva: World Health Organization. Accessed from https://www.who.int/ news-room/fact-sheets/detail/epilepsy

Yeh, C.T.; Ching, L.C. and Yen, G.C. (2009). Inducing gene expression of cardiac antioxidant enzymes by dietary phenolic acids in rats. J. Nutr. Biochem., 20(3):163-171.

Yusuf, A.; Buraimoh, A.; Agbon, A.; Raji, K.B. and Akpulu, P. (2017). Preliminary histological studies on the effect of aqueous fruit extract of Phoenix Dactilifera L.(date palm) on lead acetateinduced cerebellar damages in wistar rats. African Journal of Cellular Pathology, 8(1):1-8.

Zheng, Q.S.; Sun, X.L.; Xu, B.; Li, G. and Song, M. (2005). Mechanisms of apigenin-7-glucoside as a hepatoprotective agent. Biomed. Environ. Sci., 18(1):65-70.

Citation: MD Imad Uddin, A. Vandana, G. Kavya and Yousuf Hussain Syed (2020). Systematic study on protective role of date palm (Phoenix dactylifera L.) on central nervous system disorders. Ann. Phytomed., 9(1):58-65. http://dx.doi.org/ 10.21276/ap.2020.9.1.7 